\title{
Structural, Optical and Antibacterial Activity of Pure and Cadmium Doped Zinc Oxide Nano Particles
}

\author{
A.Pricilla Jeyakumari ${ }^{1}$, P.Siva $^{2}$, P.Pachamuthu ${ }^{3}$, M.Revathi $^{4}$ \\ ${ }^{1,2}$ thiruvalluvar Governmentt Arts College, Rasipuram, Tamil Nadu ,India \\ ${ }^{3}$ selvam Arts And Science College, Namakkal, Tamil Nadu, India, \\ ${ }^{4}$ muthayammal Engineering College, Rasipuram, Tamil Nadu, India.
}

\begin{abstract}
Metal oxide nanoparticle is a versatile material with much scientific and industrial application. Zinc Oxide $(\mathrm{ZnO})$ and $\mathrm{Cd}$ doped Zinc Oxide were prepared by Co-precipitation method. $\mathrm{ZnO}$ nanoparticle play important role in the enhancement of dielectric properties of nano composites. The crystalline nature of the sample were also confirmed by X-ray diffraction pattern. The crystalline size of the pure and Cd doped nano particle were determined as $21 \mathrm{~nm}$ and $18 \mathrm{~nm}$. FT-IR spectra identify the functional groups present in the molecular structure. There is a shift in the low frequency region confirmed the presence of the dopant $(C d)$. The surface morphology of the prepared materials were also analysed by SEM with EDAX. The photo luminescence analysis spectrum of these samples were also recorded. It shows blue shift at $366 \mathrm{~nm}$. The energy gap value for pure and $\mathrm{Cd}$ doped $\mathrm{ZnO}$ were also determined. Anti-bacterial studies show that the zone of inhibition is high for the $\mathrm{ZnO}$ and $\mathrm{Cd}$ doped $\mathrm{ZnO}$ nano particle. $\mathrm{ZnO}$ nanoparticle shows significant antibacterial activity against bacterial species.
\end{abstract}

Keywords: Antibacterial activity, Nanoparticle, SEM with EDAX, X-ray diffraction, Zinc oxide.

\section{Introduction}

Nanoparticles are of great interest for many technical applications and fundamental research due to the dependent physical properties[1-4]. Nanostructure materials have received broad attention due to their distinguished performance in electronics, optics and photonics. Zinc oxide is a unique material that exhibits semiconducting and peizoelectronic dual properties. From the 1960s, synthesis of $\mathrm{ZnO}$ thin films has been an active field because of their applications as sensors, transducer and catalyst [5]. $\mathrm{ZnO}$ is an interesting chemically and thermally stable-type semiconductor with wide direct band gap of $3.37 \mathrm{eV}$ at room temperature and high sensitivity to toxic and combustible gases [6].Compared with other semiconductor materials $\mathrm{ZnO}$ has higher excitation binding energy $(60 \mathrm{meV})$ and has been studied as an optoelectronic, transparent conducting, and piezoelectric material. Thus, the synthesis of $\mathrm{ZnO}$ nanoparticles by direct precipitation method is simple, fast and eco-friendly in nature [7]. Recently, $\mathrm{Mn}$-doped $\mathrm{ZnO}$ nanoparticles was used in the optical device in diluted magnetic semiconductor materials[8].The $\mathrm{Cu}$-doped $\mathrm{ZnO}$ has sensor RT sensitivity, faster response time, and good selectivity. Miniaturized $\mathrm{Cu}$-doped $\mathrm{ZnO}$ rod based sensor can server as a good candidate for effective $\mathrm{H} 2$ detector with low power consumption.[9]. Different size of $\mathrm{ZnO}$ nanoparticles were formed because of different environment of laser pulse generated and the blue shift in the absorption edge indicated the quantum

confinement property of nanoparitcles.[10]Motivated by the above work in the present investigation pure and $\mathrm{Cd}$ doped $\mathrm{ZnO}$ have been prepared by Co-precipitation method and characterized by powder $\mathrm{X}$-ray diffraction method and FT-IR spectrum. The morphology of the nanoparticles were studied by scanning electron microscopy ( SEM ) method. The optical properties were also determined from UV-Visible spectroscopy and photoluminescence spectra. The antibacterial activity of pure $\mathrm{ZnO}$ and $\mathrm{Cd}$-doped $\mathrm{ZnO}$ nanoparticles were also studied.

\section{Experimental}

\subsection{Synthesis of pure $\mathrm{ZnO}$ and $\mathrm{Cd}$ doped $\mathrm{ZnO}$ Nanoparticles}

$\mathrm{ZnO}$ nanoparticles were prepared by economically less Co-precipitation method [11,12] . A $0.2 \mathrm{M}$ of zinc acetate ( $\mathrm{Zn} \mathrm{C4H6O4)} \mathrm{was} \mathrm{dissolved} \mathrm{in} 20 \mathrm{ml}$ of absolute ethanol and stirred at room temperature for 30 min. Then $36 \mathrm{mg}$ of $\mathrm{NaOH}$ was dissolved in $20 \mathrm{ml}$ of ethanol. The $\mathrm{NaOH}$ solution was added to the zinc acetate solution in drop wise in constant stirring. The $\mathrm{pH}$ value of the solution was measured to be 12 . The solution was continuously stirred for 2 hours at room temperature. The solution became turbid form which indicated the $\mathrm{ZnO}$ nano particles were formed. The solution was filtered and precipitates were collected and washed with distilled water and absolute ethanol and acetone for several times. The final product was annealed at $200^{\circ} \mathrm{C}$ for 1 hour.

National Conference on Current Advancements in Physics $3^{\text {rd }} \& 4^{\text {th }}$ February 2017 $80 \mid$ Page Department of Physics, St. John's College, Palayamkottai-627 002, Tamilnadu, India. DOI 10.9790/4861-17002038086 
The resultant $\mathrm{ZnO}$ nanoparticles were collected and sealed in plastic container. Cd doped $\mathrm{ZnO}$ Nanoparticles were prepared by the above said procedure with the addition of $0.002 \mathrm{M}$ cadmium sulphate in $20 \mathrm{ml}$ ethanol.

\subsection{Structural characterization}

\section{Results and Discussion}

\section{a) XRD Pattern}

The phase composition and the crystalline size of the prepared $\mathrm{ZnO}$ sample were evaluated by $\mathrm{X}$-ray diffraction analysis. Fig.3.1 presents the XRD pattern of pure $\mathrm{ZnO}$ nanoparticles annealing at temperature of $200^{\circ} \mathrm{C}$. The sharp and high intensity diffraction peak are corresponding to the $\left(\begin{array}{lll}1 & 0 & 1\end{array}\right)$ plane. The various crystal

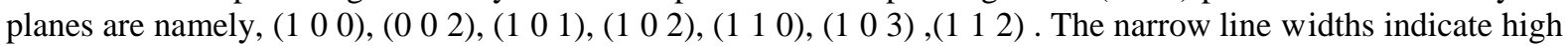
crystalline nature of the synthesized material. The scan range of 20-80 degrees contained a strongest line for hexagonal phase[13] as shown in Fig.3.1. The X-ray diffraction very well agreed with hexagonal phase of $\mathrm{ZnO}$ in JCPDS 36-1451. The lattice parameters a and c were calculated using Eq. (1),

$$
\frac{1}{d^{2}}=\frac{h^{2}+k^{2}}{a^{2}}+\frac{l^{2}}{c^{2}}
$$

The average crystalline size of all the samples was calculated using Debye-Scherrer formula

$$
\mathrm{D}=\frac{0.9 \lambda}{(\beta \cos \theta)}
$$

Where $\lambda$ is the wavelength of X-ray radiation, $\beta$ is the full width at half maximum (FWHM) of the peaks and $\theta$ is the angle of diffraction. The calculated crystallite size was found to be $21 \mathrm{~nm}$ for $\mathrm{ZnO}$ nanoparticles. The lattice parameter are $a=b=3.2417 \AA$ and $c=5.1850 \AA$. The same procedure was adopted to calculate the particle size of $\mathrm{Cd}$-doped $\mathrm{ZnO}$ and it is found to be $18 \mathrm{~nm}$. The crystal planes of Cd-doped $\mathrm{ZnO}$ are as follow (l $\left.\begin{array}{lll}1 & 0 & 1\end{array}\right),\left(\begin{array}{lll}1 & 0 & 2\end{array}\right),\left(\begin{array}{lll}2 & 0 & 2\end{array}\right)$. The XRD pattern of Cd-doped $\mathrm{ZnO}$ are shown in fig 3.1
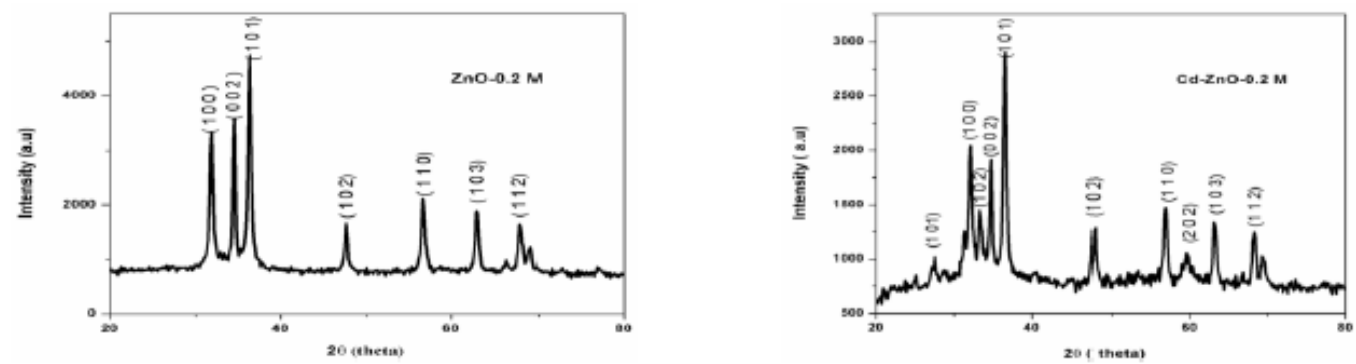

Fig.3.1.X-Ray diffraction patterns of pure $\mathrm{ZnO}$ and $\mathrm{Cd}$ doped $\mathrm{ZnO}$ nanoparticles

\subsection{FT-IR analysis}

Infrared spectroscopy was used to detect the functional group absorbed on the surface of synthesized nanoparticles during precipitation process. Fig 3.2 represents the FT-IR spectra of ZnO nanopowder recorded in the range 3200-3500 cm-1 using JASCO-FTIR 460 plus spectrometer. The peak centred at $3318 \mathrm{~cm}-1$ corresponding to the stretching vibration of intermolecular hydrogen bond ( $\mathrm{O}-\mathrm{H})$ existing between the absorbed water molecules and indicates the higher amount of hydroxyl group. The results were well matched with the observation done by samirabagheri et al [14]. The two weak bonds at 2996 and $2927 \mathrm{~cm}-1$ corresponding to the $\mathrm{C}-\mathrm{H}$ stretching modes. The bend near at $2108 \mathrm{~cm}-1$ bending vibration of the intercalated $\mathrm{O}=\mathrm{C}=\mathrm{O}$ species produced by the structure group. The weak bend at $645-831 \mathrm{~cm}-1$ appearing in IR spectrum of annealed ( $200^{\circ} \mathrm{C}$ ) compound indicates the presence of stretching and bending vibration of the intercalated $\mathrm{C}-\mathrm{O}$ species. The characteristic peak around $462 \mathrm{~cm}-1$ becomes stronger, indicating the formation of stretching mode of $\mathrm{ZnO}$. This indicates the presence of $\mathrm{ZnO}$ nanoparticles in annealed compound. The vibrational frequency $564 \mathrm{~cm}-1$ is absents in pure $\mathrm{ZnO}$. It also confirm the presence of $\mathrm{Cd}$-doped in $\mathrm{ZnO}$ angle lattice as shown in the fig 3.3. the vibrational frequency of $\mathrm{ZnO}(464 \mathrm{~cm}-1)$ is shifted to the lower frequency side $(430 \mathrm{~cm}-1)$ in $\mathrm{Cd}-\mathrm{ZnO}$ indicates the presence of the $\mathrm{Cd}$ in the Zno nano lattice. 


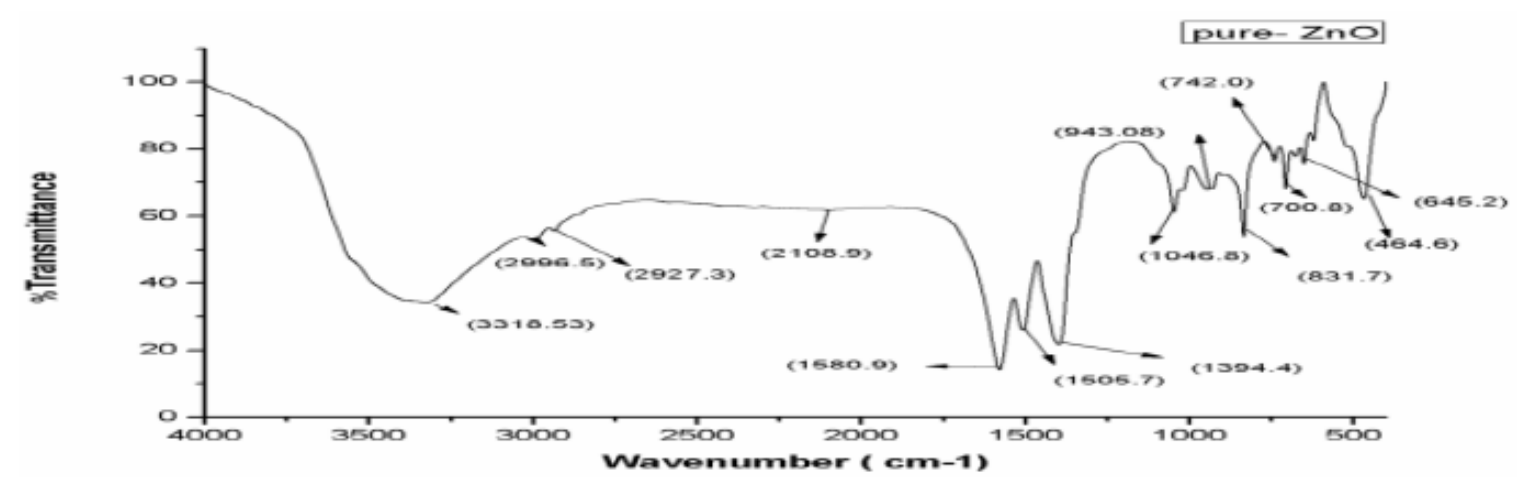

Fig:3.2 FT-IR spectra of pure $\mathrm{ZnO}$ nanoparticles

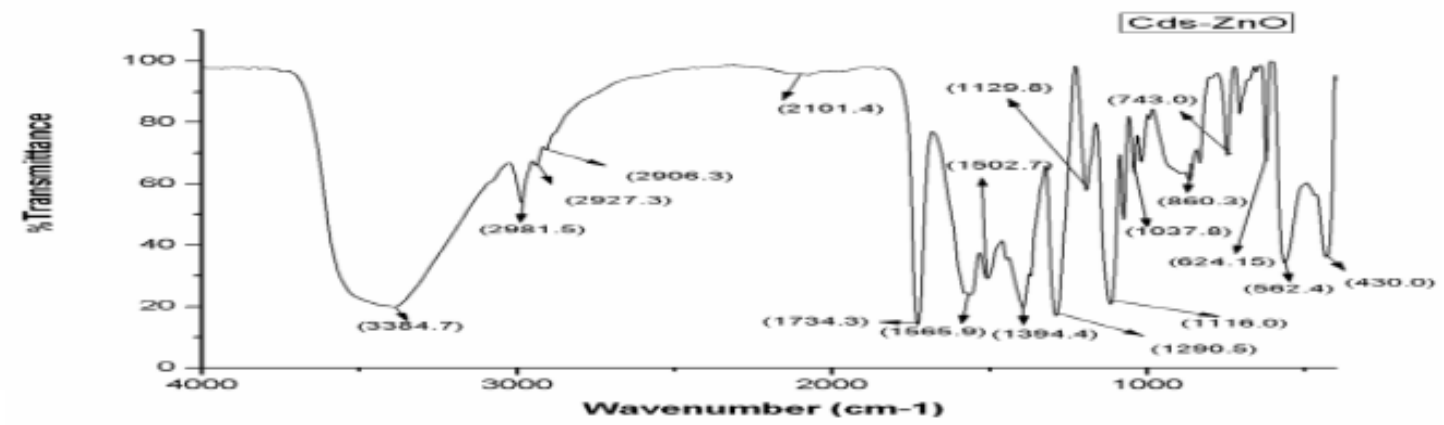

Fig: 3.3 FT-IR spectra of Cd-doped $\mathrm{Z}$ nO nanoparticles

\subsection{Scanning electron microscopy (SEM)}

Fig 3.4 shows scanning electron microscopy (SEM) micrograph of pure $\mathrm{ZnO}$ nanoparticles scanned by $10 \mathrm{kV}$ electron beam at 20,000 x magnification[15]. The SEM image reveals the polycrystalline, porous morphology with the inter-connected grains present on the pure $\mathrm{ZnO}$ nanoparticles. The small crystalline agglomerated to form nano fused clusters seen in the surface morphology of pure $\mathrm{ZnO}$. Fig 3.5 (a) shows scanning electron microscopy (SEM) micrograph of Cd-doped $\mathrm{ZnO}$ nanoparticles scanned by $20 \mathrm{kV}$ electron beam at 20,000 x magnification reveals the hexagonal shaped nanorods and pencil shaped nano particle. Similarly fig 3.5 (b) shows the image scanned by $20 \mathrm{kV}$ electron beam at 10,000 x magnification reveals the Nano crystalline structure of Cd-doped $\mathrm{ZnO}$. The magnification power increases as 55,000 x and 30,000 x exhibits the nano plates of Cd-doped $\mathrm{ZnO}$ nanoparticles ( fig 3.5 (c) and (d) ). The EDAX confirm the element present in $\mathrm{ZnO}$ shown in fig (3.6).

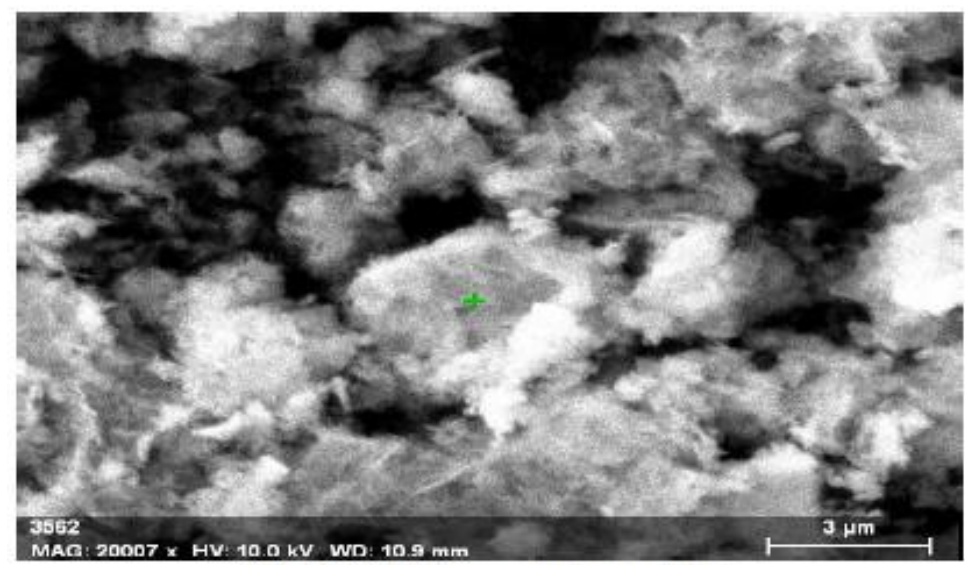

Fig 3.4 SEM image of pure $\mathrm{ZnO}$ 


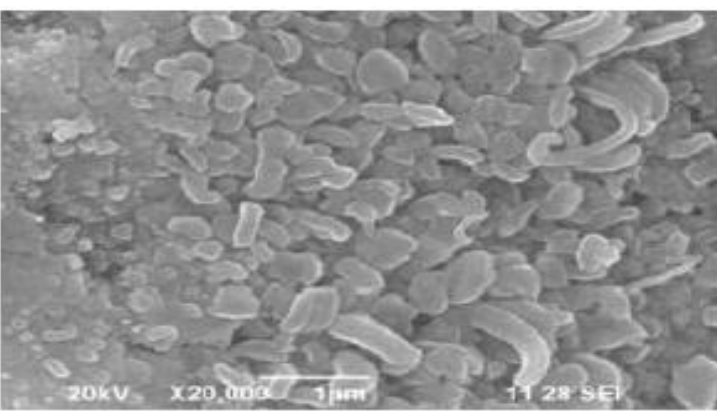

(a)

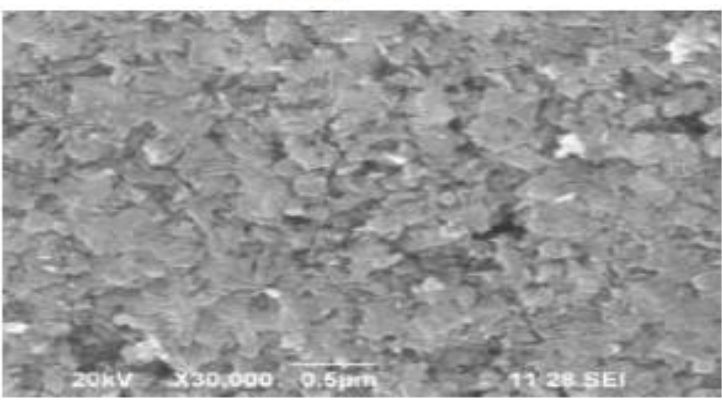

(c)

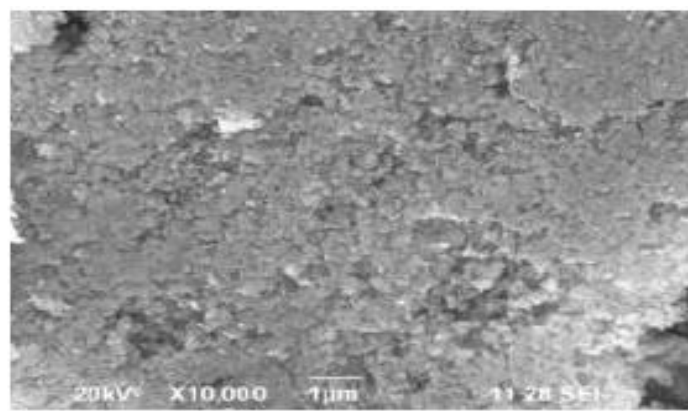

(b)

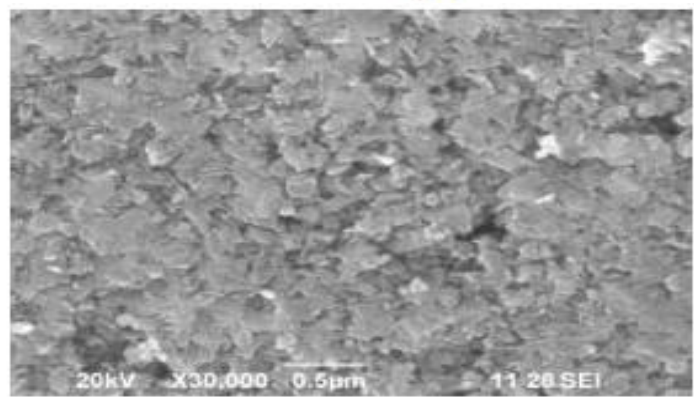

(d)

Fig 3.5 SEM image of Cd-doped $\mathrm{ZnO}$

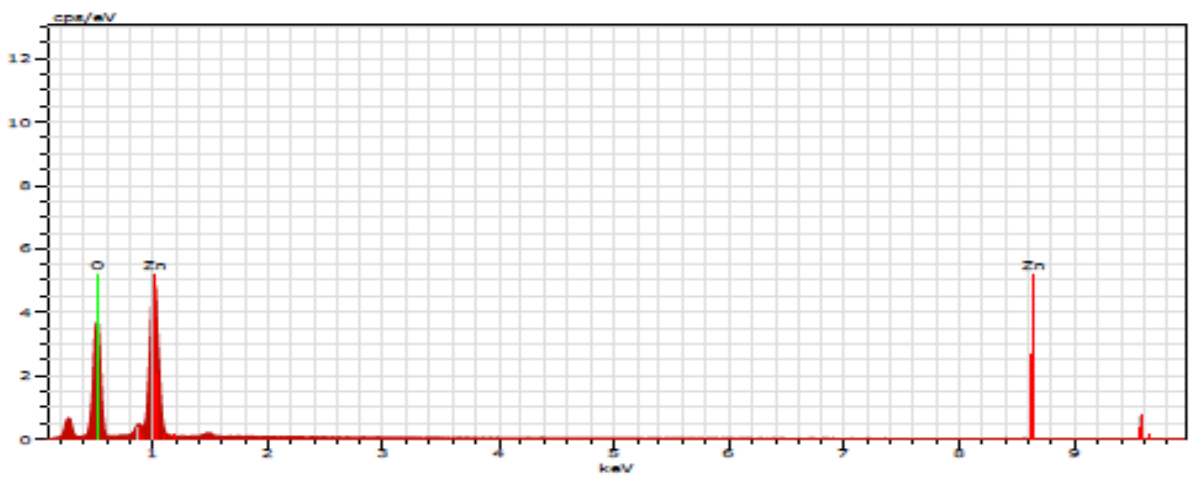

Fig 3.6 EDAX spectrum of $\mathrm{ZnO}$

\subsection{UV-Vis Spectra Optical Studies}

Optical properties like optical transmittance and optical absorption are the two important parameters to be considered in the fabrication of optical devices[12]. The UV-Vis absorption spectra recorded using LAMDA UV-spectra photometer. The UV-vis spectra of pure $\mathrm{ZnO}$ shows the absorption band at $357 \mathrm{~nm}$ shown in the fig 3.7 after that its shows less absorption, i.e ( highly transparent).and also $\mathrm{Cd}$-doped $\mathrm{ZnO}$ shows the absorption band at $345 \mathrm{~nm}$ as shown in fig 3.8.The Pure $\mathrm{ZnO}$ and $\mathrm{Cd}$-doped $\mathrm{ZnO}$ has large optical transmittance window in the region $400-800 \mathrm{~nm}$. There is no remarkable absorption band found in the region. Wide transparency region is the one of the criteria of the nano device fabrications and applicable for opto-electronics. The band gap (Eg) of pure $\mathrm{ZnO}$ and $\mathrm{Cd}$-doped $\mathrm{ZnO}$ nanoparticle were calculated by the formula $\mathrm{Eg}=\mathrm{hc} / \lambda$, where $\mathrm{h}=$ plancks constant, $\mathrm{c}=$ velocity of the light and $\lambda=$ wavelength. The corresponding band gaps were found to be $3.1 \mathrm{eV}$ and $3.2 \mathrm{eV}$ as shown in fig 3.9 (a) and (b). 


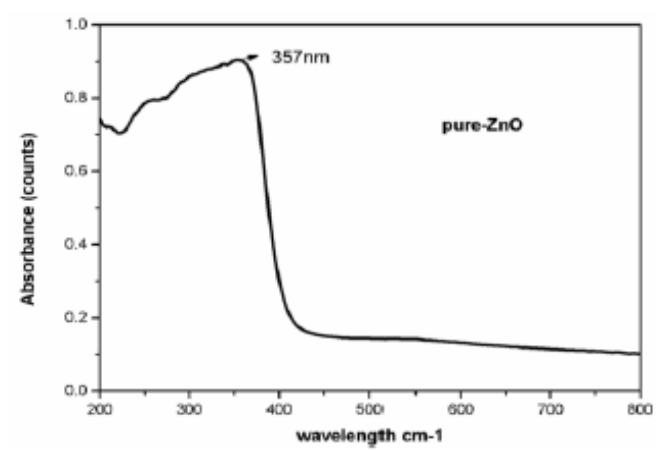

Fig 3.7 UV-Vis spectra of pure $\mathrm{ZnO}$

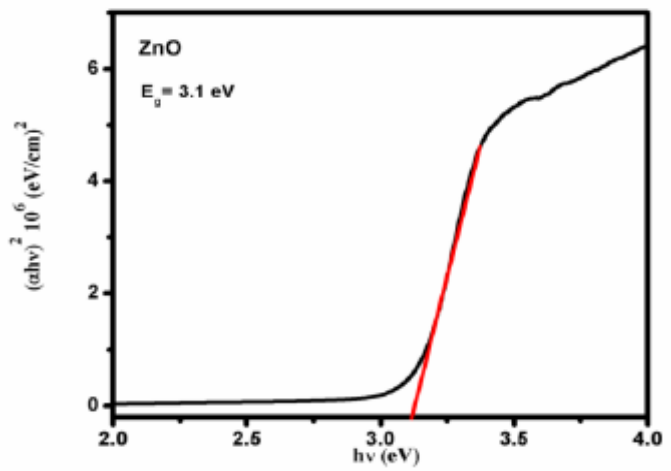

Fig 3.9 (a) Band gap graph for pure $\mathrm{ZnO}$

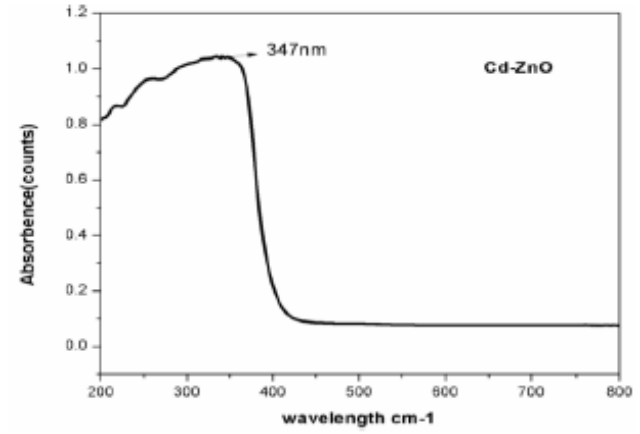

Fig 3.8 UV-Vis spectra of Cd-doped $\mathrm{ZnO}$

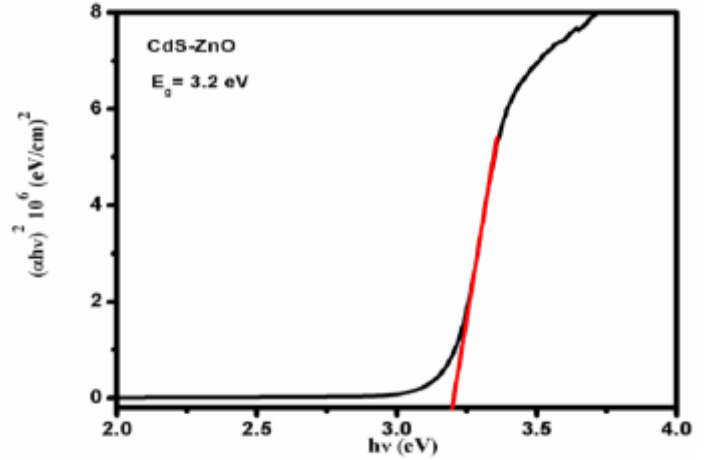

(b) Band gap graph for Cd-doped $\mathrm{ZnO}$

\subsection{Photoluminescence}

Photoluminescence spectrum (PL) of these sample were recorded at room temperature and the excitation wavelength of pure $\mathrm{ZnO}$ and $\mathrm{Cd}$-doped $\mathrm{ZnO}$ are $366 \mathrm{~nm}$ and $387 \mathrm{~nm}$. Compared with pure $\mathrm{ZnO}$ the peak position $\mathrm{Cd}$-doped $\mathrm{ZnO}$ nanoparticles shows a blue shift. The vacancy related emission was observed at $524 \mathrm{~nm}$ implies that $\mathrm{Cd}$-doped $\mathrm{ZnO}$ nanoparticles have abounded with oxygen vacancy [fig 3.10]. the oxygen vacancies are occupied by $\mathrm{Cd}$ atoms in the $\mathrm{ZnO}$ lattice.

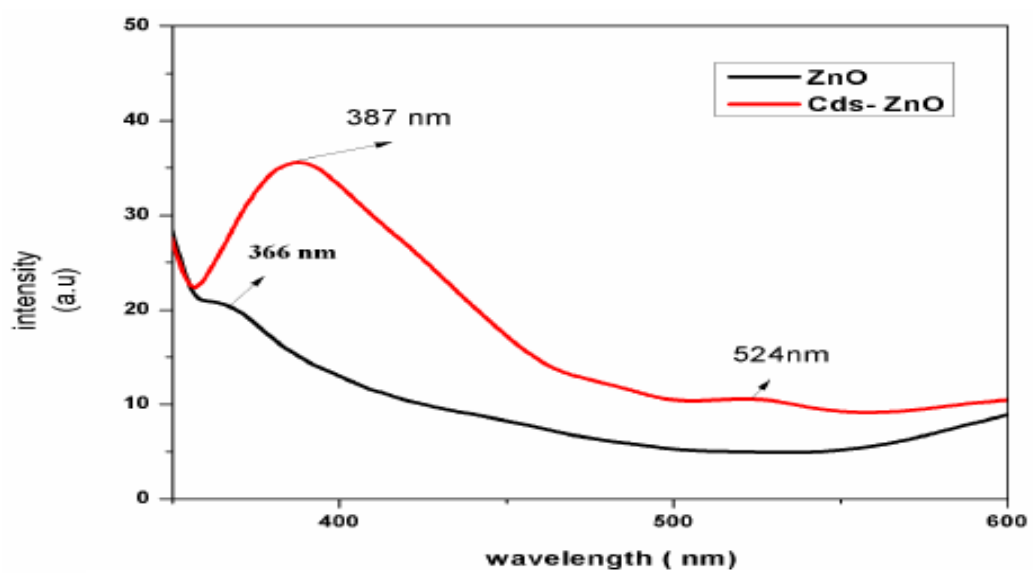

Fig 3.10 PL spectrum of pure and Cd doped $\mathrm{ZnO}$ nanoparticles

\subsection{Antibacterial activity}

Many antibacterial studies were made using different nanoparticles. The reason for the bactericidal activity is due to presence of reactive oxygen species (ROS) generated by different nanoparticles. Chemical interaction between hydrogen peroxide and membrane proteins or between the chemical produced in the presence of pure and $\mathrm{Cd}$ doped $\mathrm{ZnO}$ nanoparticles and the outer bilayer of bacteria could be the reason for the antibacterial activity of pure and $\mathrm{Cd}$ doped $\mathrm{ZnO}$. The hydrogen peroxide produced enters the cell membrane of bacteria and kills them. It is also noted that nanoparticles continue to be in interaction with dead bacteria once the hydrogen peroxide is generated, thus foiling further bacteria action and continue to produce and release hydrogen peroxide to the medium.[16]. In fig 3.11 ( a-d) and fig 3.12 ( a-c) bacteria is completely destroyed and National Conference on Current Advancements in Physics $3^{\text {rd }} \& 4^{\text {th }}$ February $2017 \quad 84 \mid$ Page Department of Physics, St. John's College, Palayamkottai-627 002, Tamilnadu, India. DOI 10.9790/4861-17002038086 
antibacterial activity is still active in pure and $\mathrm{Cd}$ doped $\mathrm{ZnO}$ nanoparticles. The various bacteria's like E.coli , bacillus ,S.aureus,and Proteus interacts with pure and $\mathrm{Cd}$ doped $\mathrm{ZnO}$ nanoparticles and the results were shown fig 3.11 ( a-d) and fig 3.12 ( a-c) and the zone of inhibition is given in table $3.1 \& 3.2$ respectively.

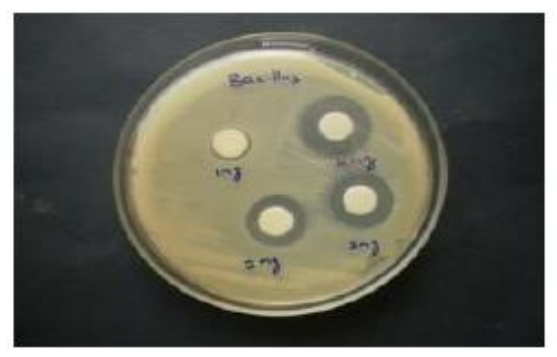

(a)

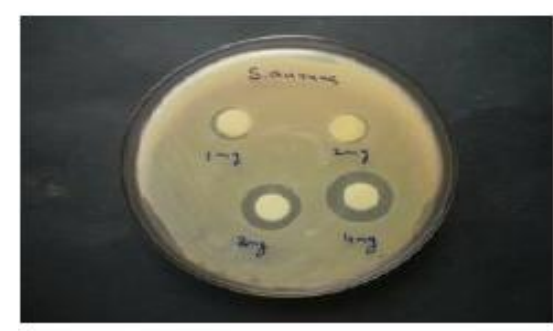

(c)

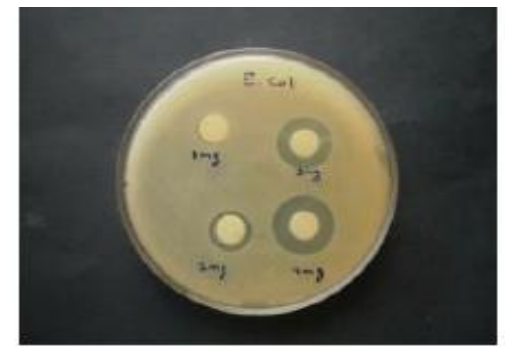

(b)

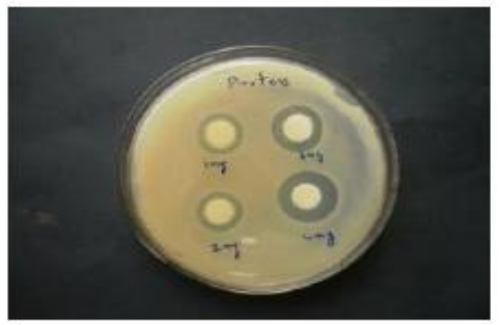

(d)

Fig 3.11 Antibacterial activity of different extracts of pure $\mathrm{ZnO}$

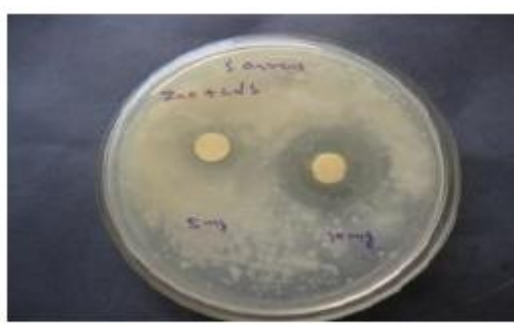

(a)

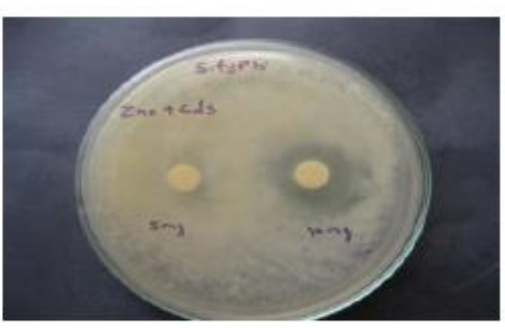

(b)

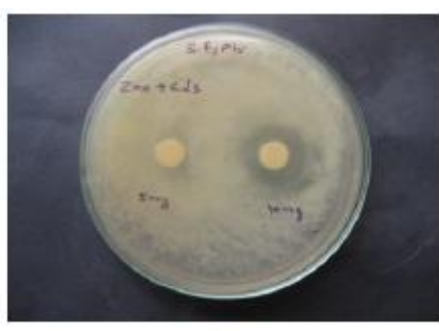

(c)

Fig 3.12 Antibacterial activity of different extracts of $\mathrm{Cd}$ doped $\mathrm{ZnO}$

Table 3.1 Antibacterial activity of different extracts of $\mathrm{ZnO}$

\begin{tabular}{|l|l|l|l|l|l|l|l|l|l|l|l|l|l|l|l|l|}
\hline \multicolumn{11}{|c|}{ Zone of inhibition } \\
\hline \multicolumn{10}{|c|}{ Escherichia coli } & \multicolumn{10}{|c|}{ Proteus vulgaris } & \multicolumn{3}{|l|}{ Staphylococcus aureus } & \multicolumn{3}{|l|}{ Bacillus subtilis } \\
\hline 1 & 2 & 3 & 4 & 1 & 2 & 3 & 4 & 1 & 2 & 3 & 4 & 1 & 2 & 3 & 4 \\
$\mathrm{mg}$ & $\mathrm{mg}$ & $\mathrm{mg}$ & $\mathrm{mg}$ & $\mathrm{mg}$ & $\mathrm{mg}$ & $\mathrm{mg}$ & $\mathrm{mg}$ & $\mathrm{mg}$ & $\mathrm{mg}$ & $\mathrm{mg}$ & $\mathrm{mg}$ & $\mathrm{mg}$ & $\mathrm{mg}$ & $\mathrm{mg}$ & $\mathrm{mg}$ \\
\hline 10 & 14 & 19 & 22 & 16 & 17 & 19 & 23 & 10 & 12 & 18 & 22 & 11 & 18 & 22 & 24 \\
$\mathrm{~mm}$ & $\mathrm{~mm}$ & $\mathrm{~mm}$ & $\mathrm{~mm}$ & $\mathrm{~mm}$ & $\mathrm{~mm}$ & $\mathrm{~mm}$ & $\mathrm{~mm}$ & $\mathrm{~mm}$ & $\mathrm{~mm}$ & $\begin{array}{ll}18 \\
\mathrm{~mm}\end{array}$ & $\mathrm{~mm}$ & $\mathrm{~mm}$ & $\mathrm{~mm}$ & $\mathrm{~mm}$ & $\mathrm{~mm}$ \\
\hline
\end{tabular}

Table 3.2 Antibacterial activity of different extracts of Cd doped $\mathrm{ZnO}$

\begin{tabular}{|c|c|c|}
\hline \multicolumn{3}{|c|}{ Zone of inhibition in mm } \\
\hline $\begin{array}{c}\text { Name of the } \\
\text { sample }\end{array}$ & Zno + CdS & $10 \mathrm{mg}$ \\
\hline $\begin{array}{c}\text { Name of the } \\
\text { microorganisms }\end{array}$ & $5 \mathrm{mg}$ & 24 \\
\hline $\begin{array}{c}\text { Staphylococcus } \\
\text { aureus }\end{array}$ & 12 & 24 \\
\hline $\begin{array}{c}\text { Salmonella } \\
\text { typhi }\end{array}$ & 13 & 24 \\
\hline
\end{tabular}

IV. Conclusions

National Conference on Current Advancements in Physics $3^{\text {rd }} \& 4^{\text {th }}$ February 2017 
Pure and Cd doped ZnO nano particles were synthesised by Co-precipitation method. The powder XRay diffraction pattern of synthesized pure and $\mathrm{Cd}$ doped $\mathrm{ZnO}$ confirmed that the materials are nanomaterials of particles size $18 \mathrm{~nm}$ and $21 \mathrm{~nm}$ respectively. The lattice parameter were determined and tabulated. The ( $\mathrm{h} \mathrm{k} 1)$ planes are also identified. The functional groups present in the pure and $\mathrm{Cd}$ doped $\mathrm{ZnO}$ nanomaterials have confirmed by FT-IR spectral analysis. The surface morphology of the samples were determined by scanning electron microscopy ( SEM ). The optical transmittance lie in the visible region is the advantage of $\mathrm{ZnO}$ used in optoelectronic application like display devices and LEDs. Low cost production is the main advantage for any product to compete in the market and $\mathrm{ZnO}$ nanostructure being their solution provides much potential to become the choice for cheap devices In addition, devices with $\mathrm{ZnO}$ nanorods exhibit better performance due to a better interfacial contact, having fewer defects and improved light extraction. The optical energy gap of the pure and $\mathrm{Cd}$ doped $\mathrm{ZnO}$ nanomaterials $(\mathrm{Eg}=3.1 \mathrm{eV}, \mathrm{Eg}=3.2 \mathrm{eV}$ ) were confirmed by UV-spectra and photoluminescence spectra. The vacancies related emission at $524 \mathrm{~nm}$ is suitable for the preparation of photovoltaic device fabrication.

References
[1]. LatifEntisar E.AL-Abodi,DhefafH.badri,Jawad Al Khafagi. preparation,characterization and electrical study of nanocomposites. American journal of polymer science, 2(6),(2012); 135-140

[2]. M.L Dinesha, G D Presanna, C S Naveen and H S jayanna.structural and dielectric properties of Fe doped $\mathrm{ZnO}$ nanoparticles. Int nal Jon puy 87(2 devices), (2013); 147-153

[3]. CuiliXiang,yongjinZou,Li-xian Sun, Fen Xu .direct electrochemistry and enhanced electrocatalysis of horseradish peroxidise based on flowerlike $\mathrm{ZnO}$-gold nanoparticles-Nafion nanocomposite. elsevier B136,(2009);158-162

[4]. K Raja , P.S . Ramesh,D.Geetha. structural,FTIR and PL studies of Fe doped ZnOnanopowder by Co-Precipitation method. Elcevier.131,(2014);183-188

[5]. Heh-Chang Huang, Tsung-EongHsieh.preparation and characterization of transparent UV-curable ZnO-acrylic nanocomposites. Elcevier.36,(2010);1245-1251

[6]. Surabhi Siva Kumar, Putchavenkateswarlu ,VanguRangaRao, Gollapallli.synthesis,characterization and optical properties of zinc oxide nanoparticles.inter nationalnano letters.3,(2013);30

[7]. Samira Bageri, Chandrappa K.G, and Sharifah Bee AbdHamid.facile synthesis of nano-sized ZnO by direct precipitation method. Scholor research library,5(3),(2013);265-270

[8]. L.BrunoChandrasekar,R.Chandramohan,S.Chandrasekarn .preparation and characterization of mn-doped $\mathrm{ZnO}$ nanoparticles. Int nano Let.5 (2015) ;71-75

[9]. L.Chow,O.Lupan,G.Chai,H.Khallaf,L.K.Ono,et al .synthesis and characterization of cu doped ZnO one dimensional structure for miniaturized sensor application with faster responce ..189,(2013);399-408.

[10]. SaharVarvaniFarahani,AzamMahmoodi,MahmoodGoranneviss. The effect of laser environment on the characterization of $\mathrm{ZnO}$ nanoparticles.Intnano let nov $\mathbf{2 0 1 5}$.

[11]. A.pricillaJeyakumari and C.Rajeswari, proc.National conference of Nanophotanics(NCNP) (2014).P.CP 1019.

[12]. A.pricillaJeyakumari and A.Gowthaman, proc.National conference of Nanophotanics(NCNP) (2014).P.CP 1034

[13]. P.D.Sahare, Vipin Kumar. Optical and magnetic properties of cu-doped $\mathrm{ZnO}$ nanoparticles .international journal of innovative technology and exploring engineering(IJITEE) 3(6),2013,2278-3075

[14]. SamiraBageri, Chandrappa K.G, and Sharifah Bee AbdHamid.facile synthesis of nano-sized ZnO by direct precipitation method. . Int nano Let,5(3),(2013);265-270

[15]. RayeesAhamedZaragar,Santhoshchackarabarati,Manjuarora,Aurangzepkhurramhafiz.synthesis,charct,and interpretation of screen printed nanocrystalineCdO thick film for opto-electronics application.springer ( cross mark),intnano let, published online 22jan2016.

[16]. Y.T.Prabhu.K.VenkateswaranRao,B.sivaKumari,Vemulaseshasaikumari.synthesis of $\mathrm{Fe} 3 \mathrm{O} 4$ nanoparticles and its antibacterial application.Int Nano Lett.5,(2015);85-92 